\title{
Decreased plasma and tissue isoleucine levels after simulated gastrointestinal bleeding by blood gavages in chronic portacaval shunted rats
}

\author{
S W M Olde Damink, C H C Dejong, N E P Deutz, P B Soeters
}

\begin{abstract}
Background-Previously, arterial concentrations of the essential branched chain amino acid isoleucine (Ile) were found to have decreased by more than $\mathbf{5 0} \%$ after gastrointestinal haemorrhage in patients and after intragastric blood administration in healthy humans and pigs. Hypothetically, this induced hypoisoleucinaemia could deplete tissue Ile pools. Aims-To study the effect of repeated blood gavages on arterial and tissue Ile levels during normal and impaired liver funcion.

Subjects-Male Wistar rats.

Methods-14 days after portacaval shunting or sham surgery, rats received $3 \mathrm{ml}$ bovine erythrocytes or saline at $0,1,2$, and 3 hours via a gastrostomy catheter in the duodenum. At $0,2,4,6$ and 8 hours arterial blood and at 8 hours intestine, liver, muscle, and cerebral cortex were sampled for determination of ammonia and amino acid concentrations.
\end{abstract}

Results-In both groups repeated blood administration resulted in a marked decrease in plasma Ile $(40-60 \%)$. This was accompanied by decreased tissue Ile concentrations in liver $(50 \%)$, muscle $(40-60 \%)$, and cerebral cortex $(40-50 \%)$, but unaltered intestinal Ile levels. In contrast, the arterial and tissue concentrations of ammonia, urea, and of most amino acids increased, most strikingly of the other two branched chain amino acids, valine and leucine.

Conclusions-Simulated gastrointestinal bleeding by blood gavages in rats with and without impaired liver function leads to hypoisoleucinaemia and decreased tissue Ile pools.

(Gut 1997; 40: 418-424)

Department of

Surgery,

Maastricht University,

Maastricht,

The Netherlands

$S$ W M Olde Damink

C H C Dejong

N E P Deutz

P B Soeters

Correspondence to:

Dr NE P Deutz

Department of Surgery,

Maastricht University,

PO Box 616,

NL-6200 MD Maastricht,

The Netherlands.

Accepted for publication

28 November 1996 hepatic encephalopathy. ${ }^{1}$ First evidence foren this "toxic", probably ammonia related $\overrightarrow{0}$ potential of a protein load in the gut duringliver failure was the "meat intoxication" syndrome observed in Eck fistula dogs by Hahro and colleagues in $1893 .^{2}$ Since then a hierarchy. in the ammoniagenic potential of different pro- 0 teins has been described. ${ }^{3}{ }^{4}$ More specifically in $w$ patients with liver disease, enteral adminis $\frac{\oplus}{\infty}$ tration of whole blood was more ammoniagenic than a casein hydrolysate meal $^{3}$ and $a_{-}$ meal of packed erythrocytes led to highers ammonia levels than an isonitrogenous amount of plasma. ${ }^{4}$

Observations by our group after upperco gastrointestinal bleeding in patients with normal and impaired liver function, ${ }^{5}$ and after blood meals to healthy volunteers ${ }^{6}$ and pigs, led to the hypothesis that the ammoniagenic potential of (simulated) gastrointestinal bleed ing is related to the complete absence of the essential branched chain amino acid (BCAA) isoleucine (Ile) in the haemoglobin mol- $\frac{1}{3}$ ecule, ${ }^{7-9}$ constituting about $95 \%$ of erythrocyter protein. In all these studies a more than $50 \%$. decrease in plasma Ile was observed aftero (simulated) gastrointestinal bleeding, while the concentrations of the other two BCAAs valines (Val) and leucine (Leu) reached extremely highis levels.

Simultaneously, the arterial concentrations of most other amino acids and of ammonia and urea increased. After an isonitrogenous controb meal Ile exhibited a normal postprandia) increase just as all other amino acids, while the elevation of arterial ammonia and urea levels was much less pronounced compared with the blood meal, ${ }^{7}$ suggesting a relation between theo low arterial Ile concentration and the rise ino ammonia and urea levels. This relation wast confirmed by the finding that when Ile was ${ }^{+}$ supplemented intravenously after intragastric blood administration in pigs, the hypoiso- $\frac{\text { o }}{\mathbb{D}}$ leucinaemia was prevented and the rise in arterial ammonia and urea was blunted. ${ }^{10} \cong$

These observations led to the hypothesis that the induced hypoisoleucinaemia after ( $\operatorname{simu}-$ ? lated) gastrointestinal haemorrhage mighe affect the tissue free amino acid pools of Ile This could impair tissue protein synthesis thereby leading to a net catabolic state. Since gastrointestinal bleeding is life threatening in patients with liver insufficiency, we chose here to study rats with normal and impaired liver function. Portacaval shunting in rats was used as a model of impaired liver function, since it is well known to lead to liver disuse atrophy 
and resulting liver disfuction. In the present study arterial, intestinal, liver, muscle, and cerebral cortex concentrations of ammonia and amino acids were measured after repeated enteral administration of blood protein in rats that had received a chronic portacaval shunt, or a sham operation.

\section{Methods}

ANIMALS

Male specified pathogen free Wistar rats $(\mathrm{n}=24 ; 330$ (SD 30) $\mathrm{g}$, random bred Wistar/CPB:WU/Bor, Winkelmann, Borchen, Germany) were housed under standard conditions (not reallocated for at least 1 week, 12 hour light-dark cycle) and received standard rat chow (SRMA 20, Hopefarms, Woerden, The Netherlands) and water ad libitum until surgery. All animal use procedures were performed by licensed personnel and in accordance with the recommendations of the Guide for the Care and Use of Laboratory Animals, as applied in our institute. ${ }^{11}$

\section{EXPERIMENTAL GROUPS}

Before surgery, rats were randomly assigned, based on a tail number and computer generated random tables, to one of two experimental groups.

\section{Portacaval shunt group}

This group consisted of 12 rats in whom portacaval shunting (PCS) was performed applying Funovics' button technique using polyethylene buttons (ID $0.17 \mathrm{~cm}$, OD $0.23 \mathrm{~cm}$ ) as described recently. ${ }^{12}$ After resuscitation from surgery, these PCS rats were placed in metabolic cages with free access to standard rat chow and water. Their daily food intake was recorded and this amount was administered to their individual sham mates (pairfeeding) to eliminate the effects of the differences in food intake normally seen between PCS and sham operated rats. ${ }^{13}$

\section{Sham group}

These 12 rats underwent laparotomy and manipulations as in PCS rats, but no shunting was performed (sham operation). Rats were allowed to recover, placed in metabolic cages, and pairfed with their individual PCS mate. All rats were studied 14 days after surgery (see below).

\section{SURGICAL PROCEDURES}

All operations were performed in overnight fasted rats at room temperature under ether anaesthesia at constant body temperature. Portacaval shunting and sham surgery were performed as previously described. ${ }^{12}$

Fourteen days after sham or portacaval shunt surgery, the right femoral artery was catheterised for blood sampling with a heparinised PE-50 catheter (Intramedic polyethylene tubing PE-50, ID $0.058 \mathrm{~cm}$, OD $0.096 \mathrm{~cm}$, Clay Adams, Parsippany, NJ, USA) and fixed in place with silk ligatures. For enteral administration of bovine packed erythrocytes or saline, a gastrostomy catheter (ID $0.10 \mathrm{~cm}$; OD $0.18 \mathrm{~cm}$; Tygon Westvaco, Cleveland, $\mathrm{OH}, \mathrm{USA}$ ) was placed with its tip in the duodenum via a purse string suture in the stomach. Hereafter, all catheters were sealed and tunnelled subcutaneously to the neck, where they were exteriorised. The rats were placed back in their cages and allowed to recover. Finally, rats of each group were, again based on their tail number, randomly assigned to subgroups receiving either blood or saline meals.

BLOOD/SALINE ADMINISTRATION AND

SAMPLING (SEE FIG 1)

Bovine erythrocyte packed cells were prepared by a single centrifugation step and stored at $-70^{\circ} \mathrm{C}$ before use (one batch, protein amount $180 \mathrm{~g} / \mathrm{l}$ ). Bovine erythrocytes were used to simulate the bleeding, because, as in human erythrocytes, both the $\alpha^{14}$ and the $\beta^{15}$ chain of bovine haemoglobin are completely deficient in isoleucine, whereas rat $\alpha^{16}$ and $\beta^{17}$ chains

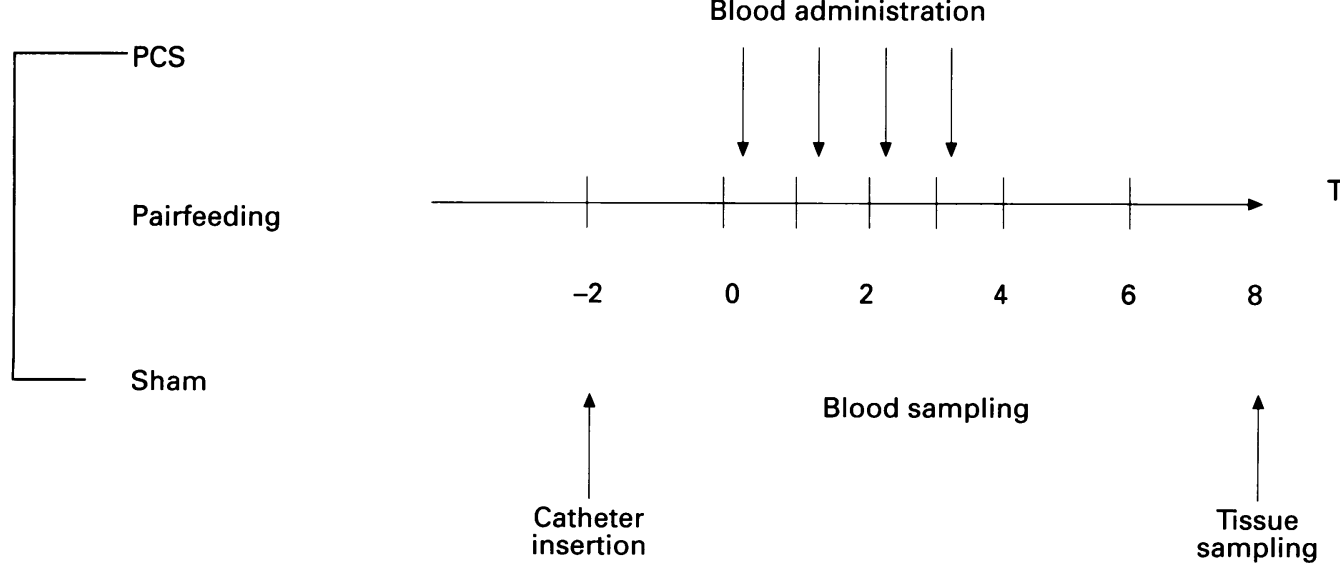


contain some isoleucine molecules. Two hours after catheter insertion, at $0,1,2$, and 3 hours, the conscious and unrestrained rats received either $3 \mathrm{ml}$ of bovine erythrocytes or $3 \mathrm{ml}$ of saline at room temperature through the gastric catheter.

At $0,2,4,6$, and 8 hours, before intragastric blood or saline administration, $0.5 \mathrm{ml}$ arterial blood was slowly sampled (at a rate of $1.0 \mathrm{ml}$ / min) in heparinised cups (Microvette LH CB1000, Sarstedt, Nümbrecht, Germany). At 0 and 8 hours, for blood $\mathrm{pH}$ measurements, $0.4 \mathrm{ml}$ of arterial blood was sampled anaerobically and determined immediately on a blood gas analyser (ABL520, Radiometer, Copenhagen, Denmark). Sample volumes were substituted with normal saline at $37^{\circ} \mathrm{C}$ via the arterial catheter. Immediately after completion of the sampling, at 8 hours, tissue samples were harvested. The small bowel was grasped at Treitz's ligament, freed from its mesentery and flushed with normal saline after which approximately $10 \mathrm{~cm}$ of jejunum was freeze clamped with Wollenberg tongs cooled in liquid nitrogen. ${ }^{18}$ Hereafter, the left liver lobe, the left gastrocnemius muscle, and finally the cerebral cortex of one hemisphere were rapidly excised, freeze clamped in liquid nitrogen, and stored at $-70^{\circ} \mathrm{C}$.

BIOCHEMICAL ANALYSIS

After sampling, blood was promptly kept on ice. Within 10 minutes, centrifugation was performed at $4^{\circ} \mathrm{C}$ at $8800 \mathrm{~g}$ for 5 minutes. A volume of $100 \mu \mathrm{l}$ of plasma for amino acids was deproteinised with $4 \mathrm{mg}$ sulphosalicylic acid, immediately put into liquid nitrogen, and stored at $-70^{\circ} \mathrm{C}$. Ammonia and urea were determined spectrophotometrically in plasma by standard enzymatic methods on a centri-

TABLE I Arterial concentrations expressed as means (SEM) in $\mu M$, except urea in $m M$. Data are given for $t=0 h$ and $t=8 \mathrm{~h}$

\begin{tabular}{|c|c|c|c|c|}
\hline \multirow[b]{2}{*}{ Time (h) } & \multicolumn{2}{|l|}{ Sham } & \multicolumn{2}{|l|}{ PCS } \\
\hline & Saline $(n=6)$ & Blood $(n=5)$ & Saline $(n=4)$ & Blood $(n=5)$ \\
\hline \multicolumn{5}{|l|}{ Ammonia } \\
\hline $\begin{array}{l}0 \\
8\end{array}$ & $\begin{array}{l}62(4) \\
61(11)\end{array}$ & $\begin{array}{l}67(9) \\
63(5)^{b}\end{array}$ & $\begin{array}{l}90(8) \\
78(9)^{f}\end{array}$ & $\begin{array}{c}79(6) \\
121(14)^{\mathrm{cfg}}\end{array}$ \\
\hline \multicolumn{5}{|r|}{ (1) } \\
\hline $\begin{array}{l}0 \\
8\end{array}$ & $\begin{array}{l}7 \cdot 7(0 \cdot 6) \\
6 \cdot 5(1 \cdot 0)\end{array}$ & $\begin{array}{c}9 \cdot 0(0 \cdot 6) \\
12 \cdot 8(2 \cdot 0)^{\mathrm{c}}\end{array}$ & $\begin{array}{l}8 \cdot 1(0 \cdot 5) \\
8 \cdot 6(1.6)\end{array}$ & $\begin{array}{l}8 \cdot 4(1 \cdot 1) \\
9 \cdot 8(1 \cdot 7)^{d}\end{array}$ \\
\hline \multicolumn{5}{|c|}{ (1) } \\
\hline $\begin{array}{l}0 \\
8\end{array}$ & $\begin{array}{l}69(4) \\
97(4)^{i}\end{array}$ & $\begin{array}{l}72(7) \\
60(8)^{\mathrm{cg}}\end{array}$ & $\begin{array}{c}66(3) \\
116(11)^{\mathrm{i}}\end{array}$ & $\begin{array}{l}58(4) \\
50(9)^{\mathrm{cth}}\end{array}$ \\
\hline \multicolumn{5}{|l|}{ Leu } \\
\hline $\begin{array}{l}0 \\
8\end{array}$ & $\begin{array}{l}149(15) \\
218(28)^{\mathrm{cg}}\end{array}$ & $\begin{array}{l}168(24) \\
479(128)^{\mathrm{cg}}\end{array}$ & $\begin{array}{l}192(28) \\
182(36)^{\mathrm{ch}}\end{array}$ & $\begin{array}{l}150(18) \\
341(73)^{\mathrm{ch}}\end{array}$ \\
\hline \multicolumn{5}{|l|}{ Val } \\
\hline $\begin{array}{l}0 \\
8\end{array}$ & $\begin{array}{l}184(9) \\
277(35)^{\mathrm{g}}\end{array}$ & $\begin{array}{l}205(22) \\
604(154)^{\mathrm{cg}}\end{array}$ & $\begin{array}{l}241(36) \\
237(30)\end{array}$ & $\begin{array}{l}187(16) \\
497(102)^{\mathrm{ch}}\end{array}$ \\
\hline \multicolumn{5}{|r|}{ (3) } \\
\hline $\begin{array}{l}0 \\
8\end{array}$ & $\begin{array}{l}32(2) \\
34(2)\end{array}$ & $\begin{array}{l}34(3) \\
38(2)^{g}\end{array}$ & $\begin{array}{l}45(6) \\
45(3)^{f}\end{array}$ & $\begin{array}{l}39(6) \\
50(6)^{f}\end{array}$ \\
\hline \multicolumn{5}{|r|}{$50=(20)$} \\
\hline $\begin{array}{c}0 \\
8 \\
\text { AAA }\end{array}$ & $\begin{array}{l}517(27) \\
496(26)\end{array}$ & $\begin{array}{l}509(20) \\
490(31)^{g}\end{array}$ & $\begin{array}{l}589(28) \\
532(50)\end{array}$ & $\begin{array}{l}585(30) \\
678(56)^{\text {bf }}\end{array}$ \\
\hline $\begin{array}{c}0 \\
8 \\
\alpha A N\end{array}$ & $\begin{array}{l}126(4) \\
157(8)\end{array}$ & $\begin{array}{l}138(8) \\
230(19)^{\mathrm{ci}}\end{array}$ & $\begin{array}{l}226(27) \\
226(15)\end{array}$ & $\begin{array}{l}178(16) \\
307(41)^{\mathrm{bg}}\end{array}$ \\
\hline $\begin{array}{l}0 \\
8\end{array}$ & $\begin{array}{l}2888(62) \\
3058(98)\end{array}$ & $\begin{array}{l}3008(100) \\
4387(570)^{\mathrm{cg}}\end{array}$ & $\begin{array}{l}3975(317) \\
3658(147)^{d}\end{array}$ & $\begin{array}{l}3418(204) \\
4634(665)^{b f}\end{array}$ \\
\hline
\end{tabular}

$\mathrm{AAA}=$ aromatic amino acids $\mathrm{Tyr}+\mathrm{Phe} ; \alpha \mathrm{AN}=$ the sum of the individual amino acids measured. Symbols represent ANOVA for differences between groups: blood $v$ saline: ${ }^{2} p \leq 0 \cdot 05,{ }^{b} p \leq 0 \cdot 01$, ${ }^{p} p \leq 0.001$. ANOVA for group effects within saline or blood group: sham $v$ PCS: ${ }^{d} p \leq 0.05,{ }^{\circ} p \leq 0.01$ ${ }_{\mathrm{p}} \mathrm{p} \leq 0.001$. One way procedure for time effects within groups: ${ }^{\mathrm{g}} \mathrm{p} \leq 0 \cdot 05,{ }^{\mathrm{h}} \mathrm{p} \leq 0 \cdot 01,{ }^{\mathrm{i}} \mathrm{p} \leq 0.001$. fugal analyser system (Cobas Bio, Roche Diagnostica, Hoffmann-La Roche, Basel, Switzerland) using commercial kits as detailed previously..$^{19}$ Plasma amino acids were determined with a fully automated HPLC system after pre-column derivatisation with orthophthaldialdehyde. ${ }^{20}$ Water content was determined and calculated as described previously. ${ }^{19}$

STATISTICAL ANALYSIS

Statistical analysis was performed using the SPSS/PC+ Statistical Software Package, version 3 (SPSS Inc, Chicago, IL, USA). Comparisons were made between sham and PCS rats within the blood or saline subgroup to test for group effects. Similarly, comparisons were made within the sham and PCS group between blood and saline administration to test for treatment effects. For the arterial data, analysis of variance (two way ANOVA) and for the tissue data, the Mann-Whitney $U$ non-parametric test was used. Time effects within groups were tested by one way analysis of variance. Data are presented as means (SEM); $\leq \leq 0.05$ was considered significant (see Tables I and II and Figs $2-4)$. Results on changes in behaviour and on $\vec{\theta}$ brain neurotransmitter amino acids in this model of simulated gastrointestinal bleeding by blood gavages are discussed elsewhere.

\section{Results}

During 14 days of pairfeeding PCS and sham rats had similar food intake (not shown) and body weight (day 0: 335 (8) g v 332 (4) g; day 14: 257 (9) g $v 270$ (7) g). At postmortem examination all portacaval shunts proved to be patent. Overall mortality was $16 \cdot 7 \%(n=4)$, all $\risingdotseq$ due to postoperative complications on day 1 $(n=2)$ or day $14(n=2)$.

ISOLEUCINE (TABLES I AND II AND FIGS 2-4)

Two hours after repeated blood gavages the $\frac{D}{O}$ arterial Ile levels were significantly decreased in both sham and PCS rats to approximately $50 \%$ N of initial values (Fig 2). In the control groups N arterial Ile increased after saline supplemen- N్ tation. Repeated enteral blood administration did not change the intestinal tissue Ile concentration (Fig 3). However, in the other organs $\frac{0}{\mathbb{D}}$ repeated blood gavages led to a decrease in $\stackrel{?}{+}$ tissue Ile levels in both the sham and the PCS 0 groups (Figs 3 and 4). This apparent decrease in tissue Ile concentration did not reach $\stackrel{\mathbb{\rho}}{\square}$ statistical significance for sham rats in liver $\stackrel{\mathbb{Q}}{\varrho}$ tissue.

VALINE AND LEUCINE (TABLES I AND II AND FIGS 2-4)

Blood administrations caused a marked increase in arterial Leu and Val concentrations in both sham and PCS rats, whereas saline supplementation caused no change. In both groups the sum of the tissue concentrations of Val and Leu increased in the liver and the brain and in PCS rats also in the intestine (Figs 3 and 
TABLE II Tissue concentrations expressed as means (SEM) in $\mu$ mol $\times k g$ wet weight ${ }^{-1}$ (ww)

\begin{tabular}{|c|c|c|c|c|}
\hline & \multicolumn{2}{|l|}{ Sham } & \multicolumn{2}{|l|}{$P C S$} \\
\hline & Saline $(n=6)$ & Blood $(n=5)$ & Saline $(n=4)$ & Blood $(n=5)$ \\
\hline \multicolumn{5}{|l|}{ Intestine: } \\
\hline Ammonia & $1920(231)$ & 1627 (299) & $1448(150)$ & $2273(347)^{\mathrm{a}}$ \\
\hline Ile & $155(26)$ & 115 (18) & $113(11)^{d}$ & $108(18)$ \\
\hline Leu & 384 (107) & $688(228)$ & $208(51)^{a}$ & $577(209)^{a}$ \\
\hline Val & $383(87)$ & $786(246)$ & $249(46)$ & $731(199)^{a}$ \\
\hline Met & $51(7)$ & $78(21)$ & $40(5)$ & $95(20)$ \\
\hline Gln & $627(52)$ & 697 (91) & $653(43)$ & $997(89)^{\mathrm{bd}}$ \\
\hline AAA & $320(50)$ & $535(142)$ & $265(40)$ & $663(153)^{2}$ \\
\hline$\alpha \mathrm{AN}$ & 22978 (1484) & $26248(2292)$ & $20780(978)$ & $26271(1890)^{\mathrm{a}}$ \\
\hline \multicolumn{5}{|r|}{ (5) } \\
\hline $\begin{array}{l}\text { Ammonia } \\
\text { Ile }\end{array}$ & $\begin{array}{c}879(70) \\
88(9)\end{array}$ & $\begin{array}{c}1147(267) \\
55(14)\end{array}$ & $\begin{array}{c}1164(89)^{\mathrm{d}} \\
91(14)\end{array}$ & $\begin{array}{c}1541(497)^{\mathrm{d}} \\
42(8)^{\mathrm{a}}\end{array}$ \\
\hline $\begin{array}{l}\text { Ile } \\
\text { Leu }\end{array}$ & $\begin{array}{c}88(9) \\
209(29)\end{array}$ & $\begin{array}{c}55(14) \\
455(105)^{\mathrm{a}}\end{array}$ & $\begin{array}{r}91(14) \\
213(37)\end{array}$ & $\begin{array}{r}42(8) \\
312(72)\end{array}$ \\
\hline $\mathrm{Val}$ & $267(30)$ & $646(160)^{b}$ & $290(40)$ & $586(120)^{a}$ \\
\hline Met & $23(3)$ & $24(5)$ & $20(4)$ & $20(4)$ \\
\hline Gln & $4248(304)$ & $2764(207)^{\mathrm{a}}$ & $3092(840)$ & 1999 (378) \\
\hline AAA & $121(21)$ & $205(25)^{a}$ & $147(30)$ & $190(32)$ \\
\hline$\alpha \mathrm{AN}$ & $17277(1492)$ & 18436 (1177) & $16351(750)$ & $17166(1321)$ \\
\hline \multicolumn{5}{|l|}{ Muscle: } \\
\hline Ammonia & $262(68)$ & $171(10)$ & $204(24)$ & $428(113)^{\text {ad }}$ \\
\hline Ile & $106(8)$ & $61(10)^{a}$ & $107(4)$ & $40(8)^{2}$ \\
\hline Leu & $411(81)$ & $375(92)$ & $542(29)$ & $382(164)$ \\
\hline $\mathrm{Val}$ & $260(20)$ & $401(88)$ & 251 (17) & $370(51)^{2}$ \\
\hline Met & $42(2)$ & $41(3)$ & $49(5)$ & $47(4)$ \\
\hline Gln & 1806 (115) & $1835(66)$ & $1903(149)$ & $3174(552)^{\mathrm{ad}}$ \\
\hline AAA & $208(10)$ & $264(17)^{b}$ & $269(12)^{d}$ & $352(38)^{2}$ \\
\hline \multirow{2}{*}{\multicolumn{5}{|c|}{ Cerebral cortex: }} \\
\hline & & & & \\
\hline $\begin{array}{l}\text { Ammonia } \\
\text { Ile }\end{array}$ & $\begin{array}{l}903(72) \\
49(4)\end{array}$ & $\begin{array}{l}926(81) \\
25(8)^{2}\end{array}$ & $\begin{array}{l}937(58) \\
44(2)\end{array}$ & $\begin{array}{l}1209(96)^{204} \\
28(6)^{2}\end{array}$ \\
\hline $\begin{array}{l}\text { Ile } \\
\text { Leu }\end{array}$ & $\begin{array}{l}49(4) \\
99(10)\end{array}$ & $132(19)^{\mathrm{a}}$ & $\begin{array}{l}44(2) \\
96(13)\end{array}$ & $129(8)$ \\
\hline $\mathrm{Val}$ & $131(8)$ & $160(11)^{\mathrm{a}}$ & 120 (14) & $171(14)^{a}$ \\
\hline Met & $16(3)$ & $16(4)$ & $20(2)$ & $25(8)$ \\
\hline Gln & $5436(174)$ & $5872(226)$ & $6210(306)^{d}$ & $8952(732)^{\mathrm{ac}}$ \\
\hline $\mathrm{AAA}$ & $108(19)$ & $121(37)$ & $158(16)^{d}$ & $240(25)^{\text {ad }}$ \\
\hline$\alpha \mathrm{AN}$ & 27577 (1012) & $29012(464)$ & $28582(473)$ & $32543(1409)^{\mathrm{ad}}$ \\
\hline
\end{tabular}

AAA=aromatic amino acids $\mathrm{Tyr}+\mathrm{Phe} . \alpha \mathrm{AN}=$ the sum of the individual amino acids measured Symbols: Mann-Whitney U test for differences between groups: blood $v$ saline: ${ }^{2} p \leq 0.05$, ${ }^{b} \mathrm{p} \leq 0.01,{ }^{c} \mathrm{p} \leq 0.001$; within saline or blood group: sham $v$ PCS: ${ }^{d} \mathrm{p} \leq 0.05,{ }^{e} \mathrm{p} \leq 0.01,{ }^{\mathrm{c}} \mathrm{p} \leq 0.001$.
4). In these organs, the concentrations of Val and Leu separately showed significant increases or tendencies to increase (Table II). In muscle, however, no treatment effect on tissue Leu concentration, and as a consequence the sum of Val and Leu, could be shown.

\section{OTHER OBSERVATIONS}

\section{Ammonia}

As expected, intragastric blood meals resulted in higher arterial ammonia levels than saline meals in both groups (Table I). However, only in PCS rats did this result in a significant increase with time of the already raised arterial ammonia levels. With the exception of the liver, tissue ammonia concentrations were increased after repeated blood gavages in PCS rats, whereas sham rats showed no treatment effect (Table II).

\section{Urea}

In sham rats, blood meals led to elevated arterial urea concentrations compared with saline controls (Table I). No difference could be observed in PCS rats.

\section{Glutamine}

Only in PCS rats repeated blood gavages led to an increase in arterial glutamine levels compared with their saline mates (Table I). With the
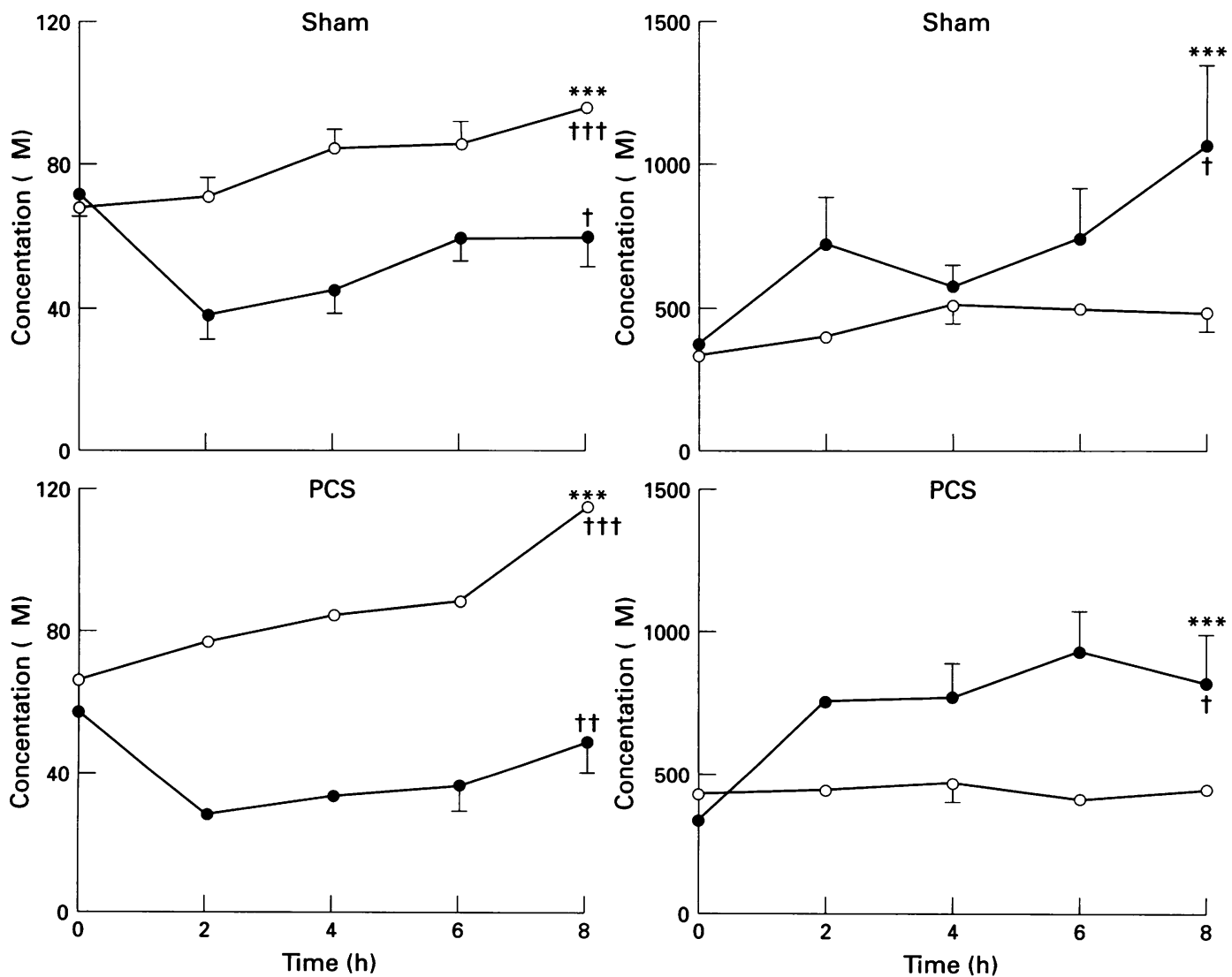

Figure 2: Arterial concentrations of Ile (left panels) and the sum of Val and Leu (right panels) in sham rats (upper panels) and PCS rats (lower panels). Open circles=subgroups receiving saline, filled circles=subgroups receiving blood. Data are means (SEM) ( $n=4-6$ per subgroup). Symbols: ANOVA for differences between groups: blood $\mathrm{v}$ saline $\star \star * p \leq 0 \cdot 001 ;$ one way procedure for time effects within groups $+p \leq 0 \cdot 05,+\dagger p \leq 0.01,+\dagger+p \leq 0.001$. 


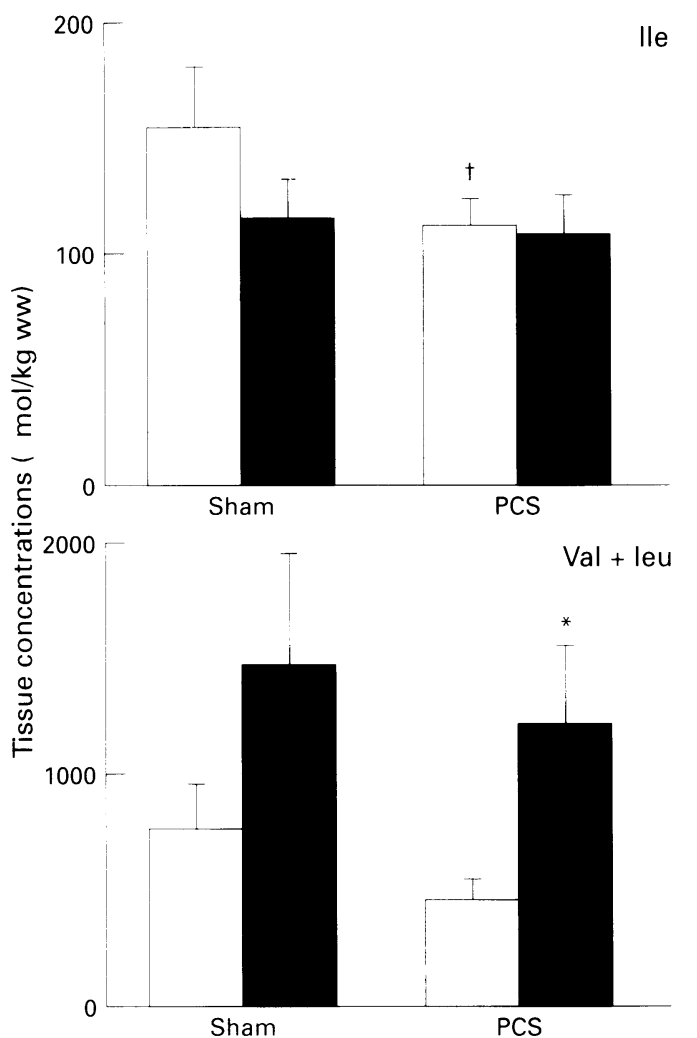

Figure 3: Intestinal (left panels) and liver (right panels) tissue concentrations of Ile (upper panels) and the sum of Val and Leu (lower panels) in sham and PCS rats following intragastric saline (open bars) or blood administration (filled bars). Data are means (SEM) ( $n=4-6$ per subgroup). Symbols: Mann-Whitney U test differences between blood and saline subgroups ${ }^{*} p \leq 0 \cdot 05$, and $\dagger p \leq 0 \cdot 05$ for differences between sham and PCS mates.
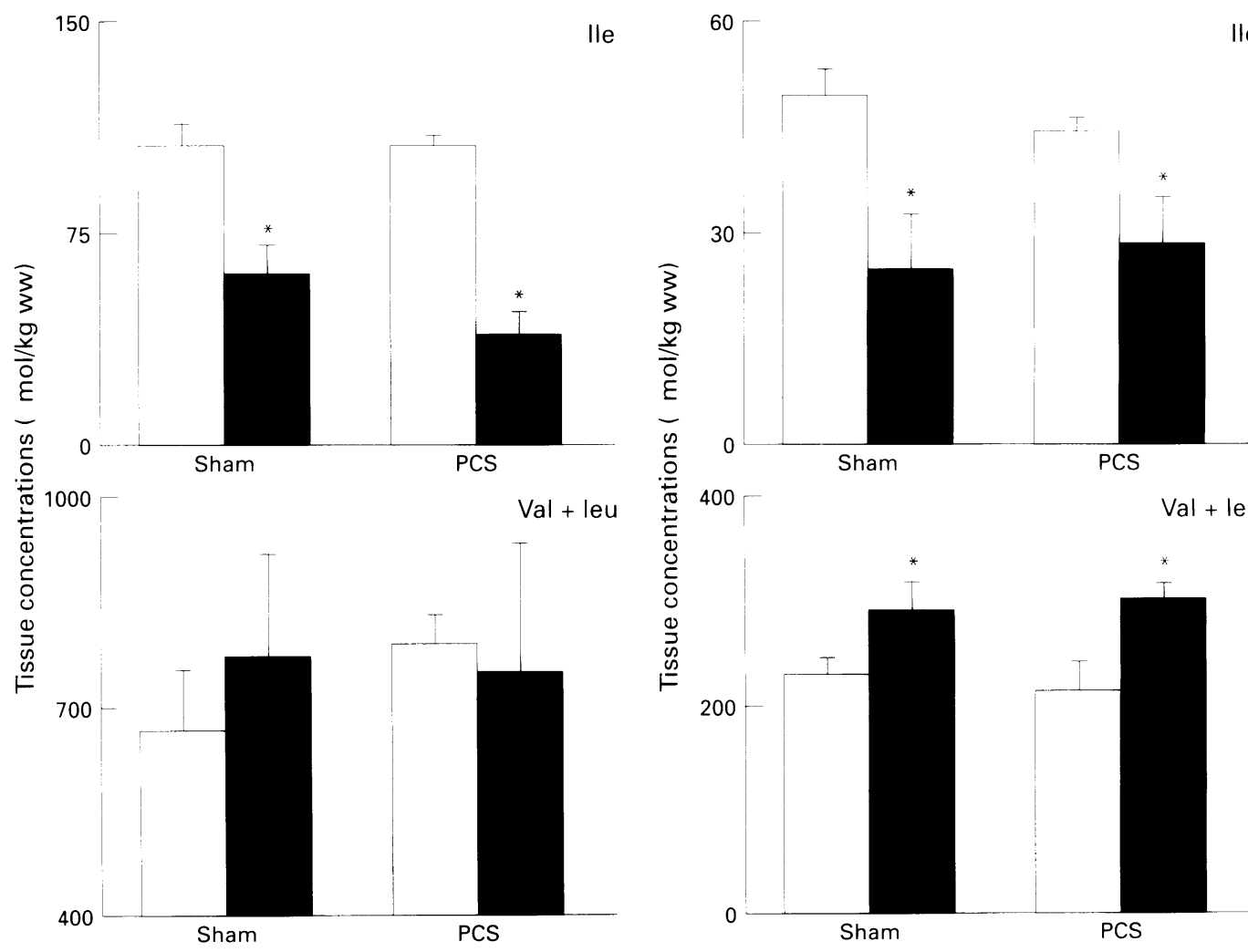

Figure 4: Muscle (left panels) and cerebral cortex (right panels) tissue concentrations of Ile (upper panels) and the sum of Val and Leu (lower panels) in sham and PCS rats following intragastric saline (open bars) or blood administration (filled bars). Data are means (SEM) (n=4-6 per subgroup). Symbols: Mann-Whitney $U$ for differences between blood and saline? subgroups ${ }^{*} p \leq 0 \cdot 05$.

exception of the liver, this hyperglutaminaemia in the PCS blood group was associated with higher tissue glutamine levels compared with the PCS saline and sham controls (Table II).
Sum of the amino acids ( $\alpha A N$ )

In both groups, plasma and tissue levels of most amino acids increased or remained unchanged after repeated blood gavages (Tables 
I and II). Repeated blood administrations led to a similar increase in arterial $\alpha \mathrm{AN}$ in sham and PCS rats (Table I). In the PCS rats only, this resulted in increased brain and intestinal tissue $\alpha \mathrm{AN}$ concentrations.

Acid-base status

No differences in blood $\mathrm{pH}$ levels were observed between the experimental groups at 0 and 8 hours (data not shown).

\section{Discussion}

The present study was undertaken to explore further the hypothesis that the occurrence of hyperammonaemia and uraemia after upper gastrointestinal bleeding is causally related to the absence of Ile in blood protein. As pointed out previously, this absence of Ile in blood protein would contribute to a decrease in plasma Ile levels after gastrointestinal bleeding. This, in turn, could hypothetically affect tissue Ile levels and consequently impair protein synthesis, contributing to a net catabolic state. If this hypothesis were correct, then it could be worthwhile to study the possibilities of treating hyperammonaemia after gastrointestinal bleeding, which is a serious complication in cirrhotics, by giving Ile simultaneously during gastrointestinal bleeding.

We examined part of the hypothesis by studying arterial and tissue amino acid concentrations. Ile decreased in arterial plasma after gastrointestinal bleeding, as we have previously observed in various species during normal and impaired liver function..$^{5-7}$ Also, in full accordance with our hypothesis (simulated) gastrointestinal haemorrhage by repeated intragastric blood administrations resulted in a decrease in tissue Ile concentrations in liver, muscle and brain to approximately $40-60 \%$ of control values in both PCS and sham rats. However, intestinal tissue Ile concentration remained unaffected.

Blood protein (mainly haemoglobin) is almost completely deficient in the essential amino acids Ile and methionine. ${ }^{7}$ Since repeated blood gavages did not change plasma or tissue methionine levels (see Tables I and II), the observed decrease in tissue and plasma Ile concentrations cannot solely be explained by the absence of Ile in the blood protein administered via the enteral route. It is probably also related to the simultaneous presence of high amounts of the other BCAAs, Val and Leu, in blood protein. ${ }^{7}$ This BCAA imbalance in the administered blood protein can lead to a phenomenon called BCAA antagonism, presumably resulting from shared BCAA transport ${ }^{21}$ and/or degradation routes (reviewed in Harper et $a l^{22}{ }^{23}$ ).

Of the latter mechanisms involved in BCAA antagonism, competition for transmembrane transport by the markedly elevated Val and Leu with the decreased Ile concentrations does not seem to play a major role in the present study, since Ile levels were similarly decreased in blood and tissue.

Another, more likely, explanation for the Ile decrease is the fact that all BCAAs initially have a shared degradation pathway. ${ }^{24}{ }^{25} \mathrm{Within}$ the cell, the initial step is a reversible, concentration dependent, transamination reaction by BCAA aminotransferase (BCAT, EC 2.6.1.42). Hereafter, the resulting 2-oxoacids undergo an irreversible oxidative decarboxylation reaction by the branched chain 2-oxoacid dehydrogenase complex (BCODC, EC 1.2.4.4), the rate limiting step in BCAA oxidation. ${ }^{24}$ Henceforth, the reaction products of the individual BCAAs follow their own catabolic pathway, for example, to the Krebs cycle. BCODC activity shows large differences between various organs because it is present in active (high content in liver) and in inactive forms (high content in muscle, brain, and intestine), ${ }^{24}{ }^{25}$ the latter being most potently activated by the 2-oxoacid of Leu. ${ }^{22}$

Accordingly, Leu concentrations in blood protein could stimulate BCAA oxidation by activating the rate limiting step of the common degradation pathway, irrespective of the level of the other BCAAs. ${ }^{22}$ Consequently, Ile oxidation will be stimulated, resulting in a further depression in plasma and tissue Ile levels, as shown in the present study. The observed decrease in tissue Ile concentrations will probably be even more pronounced intracellularly, since tissue consists of approximately $15 \%$ extracellular water ${ }^{2627}$ and plasma Ile levels exceeded tissue levels at the end of the study. Tissue Ile depression may be even more severe in the first 2 hours after intragastric blood gavages, when plasma levels were most decreased.

In the present study we did not observe a decrease in Ile concentration in intestinal tissue. This can be explained either by a low BCAA oxidation rate as both BCAT and $B C O D C$ activity are very low in the intestine, ${ }^{25}$ or by net catabolism of intestinal protein. Earlier work from our group, reporting enhanced release of amino acids, especially Val and Leu, in the portal vein after a blood meal compared with an isonitrogenous control meal provides support for a role of protein breakdown in the unchanged Ile concentration in the intestine. ${ }^{7}$ Also, a decrease in Ile might be prevented by enhanced splanchnic uptake of Ile, which occurs after Leu infusions. ${ }^{28}$

Interestingly, the simulated gastrointestinal bleeding did not increase arterial urea levels in PCS rats, although plasma ammonia and glutamine were markedly increased. This could point to a decreased urea synthesis capacity in these animals, as was shown by Steele ${ }^{29}$ in rats 14 days after portacaval shunting. The mechanism of this reduction in urea synthesis capacity cannot be deduced from our study, but could be explained by a reduction in liver weight and portacaval shunting, ${ }^{29}$ or by shunting of the small periportal area of hepatic glutaminase activity. ${ }^{30}$

The hypothesis that low tissue Ile concentrations could diminish protein synthesis is consistent with other reports concerning impaired protein synthesis, DNA synthesis, cell proliferation, and cell function in an Ile deficient state. ${ }^{31-35}$ Impaired protein synthesis could shift the balance between protein 
synthesis and breakdown towards a net catabolic state. Lecavalier $e t a l^{31}$ showed that even a short period ( 8 hours) of hypoisoleucinaemia impaired whole body protein synthesis in humans. Hypothetically, the synthetic rates of proteins with a short half life, as for instance clotting Factor VII (4 hours ${ }^{36}$ ), could be affected in such a short hypoisoleucinaemia period.

Of therapeutic interest is our previous observation that supplementing Ile intravenously after simulated gastrointestinal bleeding in normal pigs normalised the plasma Ile levels and blunted the rise in arterial ammonia and urea levels. ${ }^{10}$ We hypothesised that Ile infusion replenished the lacking Ile and thereby improved protein synthesis in various organs, resulting in a net anabolic state and less ammoniagenesis. Infusion of Ile after gastrointestinal bleeding could, therefore, hypothetically reduce the incidence of hepatic encephalopathy in patients with impaired liver function and uraemia in patients with normal liver function. In future studies we will focus on supplementing Ile as a therapeutic intervention during upper gastronintestinal haemorrhage in humans with and without impaired liver function.

In conclusion, the present study shows that simulated gastrointestinal bleeding by blood gavages during normal and impaired liver function in rats leads to hypoisoleucinaemia and a decrease in tissue lle pools in brain, muscle, and liver to approximately $40-60 \%$ of initial values. However, it had no influence on intestinal tissue Ile concentration. Depletion of Ile pools in the body could impair protein synthesis and therefore the function of rapidly dividing cells and short half life proteins, especially those with high Ile content.

The authors wish to thank $\mathrm{Mr}$ HMH van Eijk for his skilled amino acid determinations and Dr G Ramsey for carefully reading the manuscript.

1 Zieve L. Pathogenesis of hepatic encephalopathy. Metab Brain Dis 1987; 2: 147-65.

2 Hahn M, Massen O, Nencki M, Pawlow J. Die Eck'sche Fistel zwischen der unteren Hohlvene und der Pfortader und ihre Folgen für den Organismus. Arch F Exper Path u Pharm 1893; 32: 161-210.

3 Bessman AN, Mirick GS, Hawkins R. Blood ammonia levels following the ingestion of casein and whole blood. f Clin Invest 1958; 37: 990-9.

4 Bessman AN, Hawkins R. The relative effects of enterically administered plasma and packed cells on circulating blood ammonia. $¥$ Clin Invest 1963; 45: 368-73.

5 Dejong CHC, Meijerink WJHJ, van Berlo CLH, Deut NEP, Soeters PB. Decreased plasma isoleucine concentrations after upper gastrointestinal haemorrhage in humans. Gut 1996; 39: 13-7.

6 van Berlo CLH, Dejong CHC, Meijerink WJHJ, Fick TE, von Meyenfeldt MF, Deutz NEP, et al. A decrease in plasma isoleucine levels after simulated upper digestive tract bleeding in man [abstract]. Clin Nutr 1991; 10 (supp 2): 056 .

7 van Berlo CLH, van de Boogaard AEJM, van der Heijden MAH, van Eijk HMH, Janssen MA, Bost MCF, Heijden MAH, van Eijk HMH, Janssen MA, Bost MCF, digestive tract the consequence of complete absence of isoleucine in hemoglobin? A study in pigs. Hepatology isoleucine in hem

8 Hill RJ, Konigsberg W. The structure of human hemoglobin. $\mathcal{f}$ Biol Chem 1962; 237: 3151-6.
9 Lawn RM, Efstratiadis A, O'Connell C, Maniatis T. The nucleotide sequence of the human beta-globin gene. Cell 1980; 21: 647-51.

10 Deutz NEP, Reijven PLM, Bost MCF, van Berlo CLH, Soeters PB. Modification of the effects of blood on amino acid metabolism by intravenous isoleucine. Gastroenterology 1991; 101: 1613-20.

11 Guide for the care and use of laboratory animals, EEC publication, 1986: 86/609.

12 Dejong CHC, Deutz NEP, Soeters PB. Metabolic adaptation of the kidney to hyperammonemia during chronic liver insufficiency in the rat. Hepatology 1993; 18:

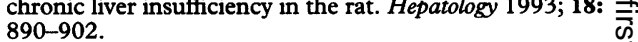

13 de Boer JEG, Ostenbroek RJ, van Dongen JJ, Janssen MA, Soeters PB. Sequential metabolic characteristics following portacaval shunts in rats. Eur Surg Res 1986; 18: 96-106. 을

14 Schroeder WA, Shelton JR, Shelton JB, Robberson B, $\bar{c}$ Babin DR. Amino acid sequence of the alpha-chain of $\vec{D}$ bovine fetal hemoglobin. Arch Biochem Biophys 1967; 120: $1-14$.

15 Schroeder WA, Shelton JR, Shelton JB, Robberson B, ڤ Babin DR. A comparison of amino acid acid sequences $\vec{O}$ in the beta-chains of adult bovine hemoglobins A and B. $O$ Arch Biochem Biophys 1967; 120: 124-35.

16 Chua CG, Carrel RW, Howard BH. The amino acid $\vec{\omega}$ sequence of the alpha chain of the major haemoglobin of o the rat (Rattus norvegicus). Biochem $\mathcal{f} 1975 ; 149: 0$ 259-69.

17 Garrick LM, Klonowski TJ, Sloan RL, Ryan TW, Garrick MD. Primary structure of the major beta chain of rat hemoglobin. Fed Proc 1977; 36: 758

18 Wollenberger A, Ristau O, Schoffa G. Eine einfache i Technik der extrem schnellen Abkülung grösserer $\vec{\infty}$ Technik der extrem schnellen Abkulung gros

19 Dejong CHC, Kampman MT, Deutz NEP, Soeters PB. 을 Altered glutamine metabolism in rat portal drained $\rightarrow$ viscera and hindquarter during hyperammonemia. Gastroenterology 1992; 102: 936-48.

20 van Eijk HMH, van der Heiden MAH, van Berlo CLH, Soeters PB. Fully automated liquid-chromatographic determination of amino acids. Clin Chem 1988; 34: $\rightarrow$ 2510-3.

21 Shotwell MA, Kilberg MS, Oxender DL. The regulation of neutral amino acid transport in mammalian cells. Biochim. neutral amino acid transport in

22 Harper AE, Miller RH, Block KP. Branched-chain amino acid metabolism. Annu Rev Nutr 1984; 4: 409-54

23 Harper AE, Benevenga NJ, Wohlhueter RM. Effects of ingestion of disproportionate amounts of amino acids. Physiol Rev 1970; 50: 428-558.

24 Wagenmakers AJM, Soeters PB. Metabolism of branched- $\mathbb{D}$ chain amino acids. In: Cynober LA, ed. Amino acid $\vec{\overrightarrow{ }}$ metabolism and therapy in health and nutritional disease. $\overline{\bar{O}}$ Boca Raton, FL: CRC Press, 1995: 67-87.

25 Ooiwa T, Goto H, Tsukamoto Y, Hayakawa T, Sugiyama S, Fujitsuka N, et al. Regulation of valine catabolism in canine tissues: tissue distributions of branched-chain aminotransferase and 2-oxo acid dehydrogenase complex, aminotransferase and 2-oxo acid dehydrogenase complex, methacrylyl-CoA hydratase and 3-hydroxyisobutyryl216-20.

26 Bergström J, Fürst P, Noreé LO, Vinnars E. Intracellular free amino acid concentration in human muscle tissue. $\mathcal{F}^{\circ} \overline{\mathrm{Q}}$ Appl Physiol 1974; 36: 693-7.

27 Cserr $\mathrm{HF}$, DePasquale $M$, Nicholson C, Patlak CS, Pettigrew KD, Rice ME. Extracellular volume decreases 0 while cell volume is maintained by ion uptake in rat brain during acute hypernatremia. F Physiol 1991; 442: D during

28 Hagenfeldt L, Eriksson S, Wahren J. Influence of leucine on arterial concentrations and regional exchange of amino $\mathrm{N}$ acids in healthy subjects. Clin Sci 1980; 59: 173-81.

29 Steele RD. Hyperammonemia and orotic aciduria in $N$ portacaval-shunted rats. $\mathcal{F}$ Nutr $1984 ; 144: 210-6$.

30 Moorman AF, de Boer PA, Watford M, Dingemans MA, N Lamers WH. Hepatic glutaminase mRNA is confined to $\sigma$ part of the urea cycle domain in the adult rodent liver lobule. FEBS Lett 1994; 356: 76-80

31 Lecavalier L, De Feo P, Haymond MW. Isolated hypo- $\frac{C}{C}$ isoleucinemia impairs whole body but not hepatic protein $\mathbb{D}$ synthesis in humans. Am $\mathcal{F}$ Physiol 1991; 261: E578-86.

32 Jakesz R, Smith CA, Aitken S, Huff K, Schuette W, Shackney $\mathrm{S}$, et al. Influence of cell proliferation and cell cycle phase on expression of estrogen receptor in MCF-7 breast cancer cells. Cancer Res 1984; 44: 619-25.

33 Kohn A. Differential effects of isoleucine deprivation on cell $\vec{D}$ motility, membrane transport and DNA synthesis in 2 NIL8 hamster cells. Exp Cell Res 1975; 94: 15-22.

34 Tobey RA, Ley $\mathrm{KD}$. Isoleucine-mediated regulation of genome replication in various mammalian cell lines. Cancer Res 1971; 31: 46-51.

35 Pittelkow MR, Wille JJ, Scott RE. Two functionally distinct classes of growth arrest states in human prokeratinocytesō 86: $410-7$.

36 Bithell TC Blood coagulation. In: Lee GR, Bithell TC, Foerster J, Athens JW, Lukens JN, eds. Wintrobe's clinical hematology. Philadelphia: Lea \& Febiger, 1993: 568. 